\title{
A Review of Eco-Innovations and Exports Interrelationship, with Special Reference to International Agrifood Supply Chains
}

\author{
María del Carmen Galera-Quiles ${ }^{1}$, Laura Piedra-Muñoz ${ }^{2, * \mathbb{D}}$, Emilio Galdeano-Gómez ${ }^{2}$ (D) \\ and Angel Carreño-Ortega ${ }^{3}$ (D) \\ 1 Foundation for Ancillary Technologies for Agriculture (TECNOVA), 04131 Almería, Spain; \\ mcgalera@fundaciontecnova.com \\ 2 Department of Economics and Business, Mediterranean Research Center on Economics and Sustainable \\ Development, CIMEDES, Agrifood Campus of International Excellence, ceiA3, University of Almería, \\ 04120 Almería, Spain; galdeano@ual.es \\ 3 Department of Engineering, CIMEDES, University of Almería, 04120 Almería, Spain; acarre@ual.es \\ * Correspondence: lapiedra@ual.es; Tel.: +34-95-001-5178
}

check for updates

Citation: Galera-Quiles, M.d.C.; Piedra-Muñoz, L.; Galdeano-Gómez, E.; Carreño-Ortega, A. A Review of Eco-Innovations and Exports Interrelationship, with Special Reference to International Agrifood Supply Chains. Sustainability 2021, 13, 1378. https://doi.org/10.3390/ su13031378

Academic Editors: Helena Carvalho and Julian Müller

Received: 22 December 2020

Accepted: 25 January 2021

Published: 28 January 2021

Publisher's Note: MDPI stays neutral with regard to jurisdictional claims in published maps and institutional affiliations.

Copyright: (c) 2021 by the authors. Licensee MDPI, Basel, Switzerland. This article is an open access article distributed under the terms and conditions of the Creative Commons Attribution (CC BY) license (https:// creativecommons.org/licenses/by/ $4.0 /)$.

\begin{abstract}
Growing environmental awareness in recent years has led to greater efforts by companies and governments to promote eco-innovation, which is becoming an increasingly competitive factor in international supply chains. However, the interrelationships between exports and eco-innovation have not yet been studied in sufficient depth. As such, the purpose of this work is to analyze the influence that exists between these two variables, both at a business or micro level and at a country/region or macro level, and the most influential factors, such as country of origin and sector of activity, among others. To this end, 60 publications have been reviewed from 1996 to 2019 from a global perspective, to analyze the characteristics that define them and both the existing relationship and impact generated by the two variables being studied within international supply chains. The results show that, in general, there is a positive bidirectional relationship, influenced by several factors, such as social performance, environmental regulation, cooperation strategies, employment level, or business size. Additionally, there is a growing interest in this issue within the agrifood sector, as the benefits of an appropriate environmental policy based on innovation to promote exports are of great importance. Finally, a series of recommendations are made for future research that is able to serve scholars, companies and also policy makers.
\end{abstract}

Keywords: sustainable innovation; international supply chains; exports; literature review; agrifood sector

\section{Introduction}

Exporting can be an effective method of achieving international standing without overstretching capacities and resources [1]. Studies on exports and international supply chains (ISC) have been broadening their search for new variables that should be considered, which include productivity, competitiveness, profitability, cooperation, regulations, company size, and innovation [2-6].

In addition, of late, there has been growing interest in environmental performance in international supply chains, which is seen as a strategic competitive factor [7-11]. Thus, one of the problems faced by different industries and companies in order to be accepted by markets, especially foreign ones, is environmental sustainability [12]. Galbreath [2] shows how exporting companies try to meet the demands of foreign markets' regarding sustainability. According to the traditional view, environmental regulations were considered detrimental to international competitiveness (e.g., Copeland and Taylor [13]), but recently some researchers have started insisting that environmental regulations positively affect international competitiveness through eco-innovation (EI) [14].

However, many companies lack interest in undertaking innovative processes to reduce environmental damage, as they do not see it as a competitive advantage to increase 
their sales abroad, but as an added expense that reduces their profitability [15]. On the other hand, environmental regulations are sometimes not sufficiently effective in terms of improving the sustainable behavior of companies [16]. All this makes it necessary to change the regulatory frameworks and incentives for companies to increase EI [17,18], and boost internationalization [2].

In this regard, improved management of environmental sustainability has helped organizations to pursue opportunities and competitive advantages, as well as promote innovations [19]. Due to increased mass production and improved technological efficiency, innovations should integrate economic, ecological, and social features to limit the impact on environmental resources [20-22]. Accordingly, innovations that improve environmental performance or eco-innovations are now attracting attention in the literature on international supply chains, although they have not yet been analyzed in sufficient depth [3,23-25]. Most of the studies carried out so far have analyzed these variables separately [26-28]. Moreover, those that have done so jointly have yielded mixed and inconsistent results. Thus, the interrelationship between these variables, as well as the main factors that influence it, is not clear. More research is therefore needed on these issues, given their importance for the environment, along with the competitiveness and productivity of companies in a global setting.

For this reason, the main aim of this paper is to provide an up-to-date review and analysis of the literature on the interrelationships between eco-innovation and international supply chains (EI-ISC). As such, the following questions need to be answered: (i) Is there any kind of relationship between EI and ISC? (ii) If so, what is its direction and is it positive or negative? (iii) What factors most influence this relationship? (iv) Are there differences at a business (micro) or regional (macro) level? Figure 1 summarizes the theoretical framework. To this end, an analysis of existing publications on EI-ISC was carried out, covering the period from 1996 to 2019 and using the main databases, such as Scopus and Web of Science, while searches were also widened using grey literature.

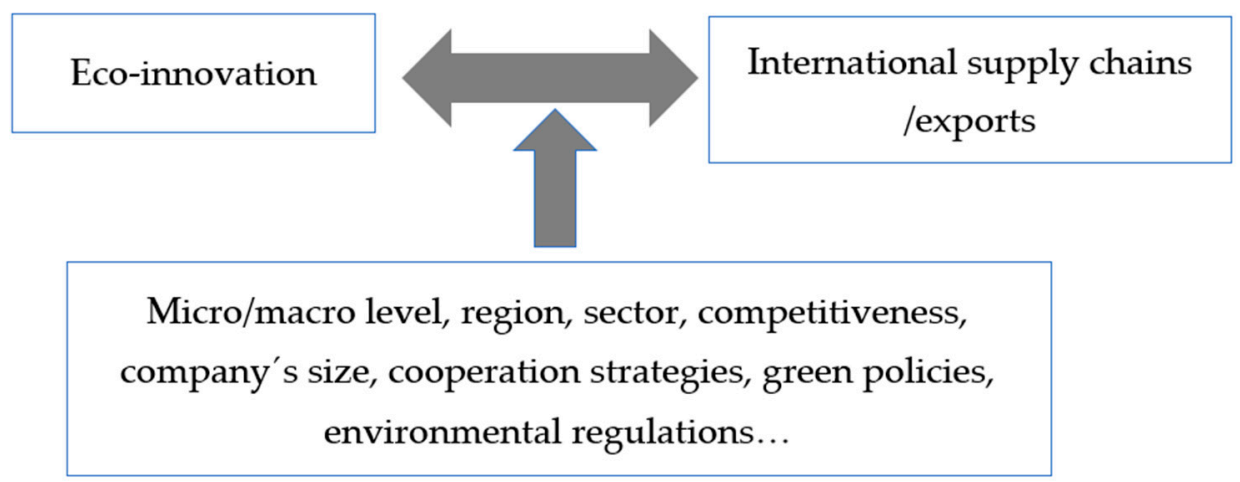

Figure 1. Theoretical framework of the study.

Furthermore, the global agricultural trade has experienced an annual growth of $6 \%$ from 2000 to 2016 [29]. Due to the environmental impact of the agrifood sector in terms of water and energy consumption together with the expansion of international trade, environmental concerns have emerged as a global problem [30]. For this reason, this study devotes a special section to EI-ISC in this sector.

Among the results, it can be observed that most of the studies exhibit a positive EI-ISC relationship. Furthermore, it is shown that the country of location of the companies making up the ISC, as well as the sector of activity, are not factors that determine the relationship being analyzed. As for the agrifood sector, EI can be considered vital for the sustainability transition and achieving food safety in ISC.

The article is structured as follows. Section 2 describes the methodology used for the selection of articles analyzed; Section 3 shows the results obtained, considering four points: (a) Conceptualization of EI and its implication on ISC; (b) general analysis of the trends in 
global research for EI-ISC; (c) analysis at a business or micro level; (d) analysis at a regional or macro level. In Section 4, close attention is paid to studies on the agrifood sector in particular. Finally, in Section 5, the conclusions and suggestions for future lines of research are set out.

\section{Materials and Methods}

To meet the goals of this review work, a search was carried out both on Scopus and Web of Science (WoS), as they are multidisciplinary databases that keep scientific articles, reviews, books, and other documents on record [31,32]. To a much lesser extent, "grey literature" was also used [33], to search through doctoral theses, congresses, books, and book chapters that served to enrich the present study. The search was carried out at the beginning of 2020 without any chronological restriction, retrieving publications from 1996 to 2019, since it was from 1996 onwards that awareness and sensitivity to this issue began to appear among scholars, companies, and stakeholders.

There are different words used in the literature to describe EI, such as "ecological", "green", "sustainable", or "environmental" innovation are used. Although several researchers have analyzed the differences between some of these terms [34,35], to keep the search as broad as possible in this study, the following terms are used to describe EI: "ecological innovation", "environmental innovation", "green innovation", "sustainable innovation", "eco-friendly innovation", and "environmentally friendly innovation" [31,36]. On the other hand, this study takes into account international supply chains [37,38], the capacity, intensity, performance, or propensity to export [5-8,23,39-41], and export capacity $[42,43]$.

The method used consists of three steps (Figure 2). Firstly, the combination of keywords searched for in the title, abstract, and keywords is: "international supply chain" OR export*) AND ("eco-innovation*" OR "ecological innovation" OR "environmental innovation" OR "green innovation" ${ }^{*}$ " OR "sustainable innovation" " OR "eco-friendly innovation*" OR "environmentally friendly innovation*"). Results of this search in WoS, Scopus, and Google scholar databases returned 264 publications. Secondly, after reading the abstracts of the documents found, those duplicated or not directly related to the topic were eliminated, as well as those that focused on only one of the two variables, leaving 112 documents. Thirdly, the papers were read in full, removing those whose aim was not to analyze the EI-ISC relationship and/or the factors influencing it or did so in a very roundabout way. In the end, a total of 60 publications were selected.

Finally, the following data were extracted from each article: The author(s), the name of the publication, the year of publication, the title, the area in which it is published, the type of study (qualitative or quantitative), the country or countries where the study was carried out, the sector of activity, possible theories adopted, the relationship found directly or indirectly between these variables, the key influencing factors, and the main results and conclusions related to the purpose of our study.

The analysis of the results generated is structured as follows:

- Conceptualization of the terms being studied.

- General analysis of the scientific production.

- Variables and interrelationships at a micro (company) and macro (country/region) level. 




Figure 2. Exclusion and inclusion criteria for the selection of the articles for review.

\section{Results}

\subsection{Conceptualisation of Eco-Innovation and Its Implication on Internationational Supply Chains}

The international supply chain (ISC) can be defined as a series of operations that guarantee that goods and services are produced and distributed in the correct amounts, delivered to chosen worldwide locations in the shortest possible time, with the objective of satisfying the needs of the foreign consumer [44]. Therefore, ISCs allow the distribution of goods and services throughout global networks [45]. Thus, they are supply chains focused on companies and organizations that are transnational.

On the other hand, EI refers to environmental innovation, green innovation, or ecological innovation [46]. In contrast to innovation in general terms, which can make a number of changes to productive activity, EI stresses the importance concerning the nature of progress towards sustainability [47]. These are innovations that contribute to a sustainable environment by bringing about ecological improvements [48-50].

There are many definitions of EI in the literature. Common to many of them is the reduction of negative externalities to the environment and the effective use of resources [51]. Rennings [47] hence defines EI as incorporating new ideas, initiatives, products, services, and processes that can reduce adverse environmental effects. According to Kemp and Pearson [34], EI is the production, assimilation, or exploitation of a product, production process, service, or a management or business method that is new to the organization (which chooses to develop or adopt it) and that results, throughout its life cycle, in a reduction of environmental risk, pollution, and other negative impacts of resource use (including energy use) compared to the alternatives. Keshminder et al. [52] refer to EI as the creation or implementation of new or significantly improved products (goods and services), processes, commercialization methods, organizational structures, and institutional arrangements that, whether intentionally or not, lead to environmental improvements compared to relevant alternatives. The United Nations Environment Program [53] defines EI as an ideal green 
economy state in which the use of energy, resources, and materials is highly efficient. As such, EI is capable of conserving and regenerating resources by increasing the efficiency of existing resources.

In addition, advanced countries with relevant technologies in this field have realized that EI is a crucial element for achieving competitive advantages in the global market [54-57]. Harabi [58] lists several reasons along these lines: Compliance with environmental regulations; securing existing markets or increasing market share; cost savings; improvement of the company's image and reputation; and a firm stance on competing innovation.

To investigate how firms are dealing with environmental sustainability issues, researchers have adopted multiple perspectives [59], from green strategies [60] and innovation [61], to sustainable supply chain management [62]. According to most of these studies, a firm should take into account the interdependence among the actors and processes within the value chain in order to effectively reduce the environmental impacts of its economic activity. Therefore, a more complete achievement of a firm's greening strategy can be obtained only by involving all the actors in the value chain, that is, the suppliers, distributors, and customers [63]. Scholars have mainly devoted their attention to upstream greening transformations of international economic activities rather than the downstream direction of the value chain [62,64], where the role of retailers and consumers is observed. Research has also stressed the role of leading firms in pushing environmental improvements of suppliers in order to develop green new products able to be competitive in international markets [61].

EI is most effective when it involves the entire value chain and is positively perceived by customers, especially when suppliers are close. Particularly when these value chains spread globally, green practices need to be understood from an international approach. The more internationalized the knowledge value chain, the greater the probability of investing in ecological processes or products as the company forms part of an international group $[15,41]$.

\subsection{General Analysis of Results}

Figure 3 shows the distribution over time regarding the set of publications analyzing the ISC-ISC relationship. It can be seen that, although the first publication found dates from 1996 [65], no more publications appear in that decade, and only in 2005 do studies start appearing again. However, the period showing the greatest interest in the subject is the last six years, in which $63.3 \%$ of the total number of publications were obtained. This provides an early indication that the study of these interrelationships is an emerging field of research.

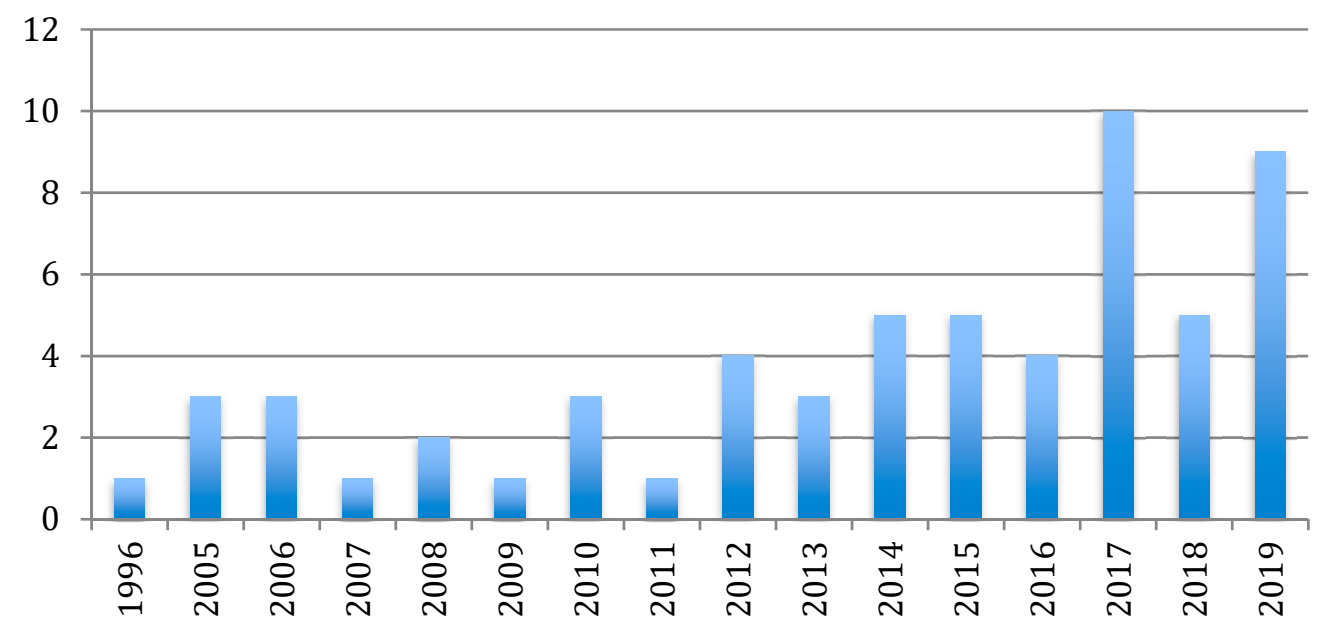

Figure 3. Time pattern for number of publications. 
Of the total number of publications selected, $75 \%$ are articles, $10 \%$ are congress proceedings, $8.3 \%$ are book chapters, and the remaining $6.6 \%$ are divided up between reviews and others (Figure 4).

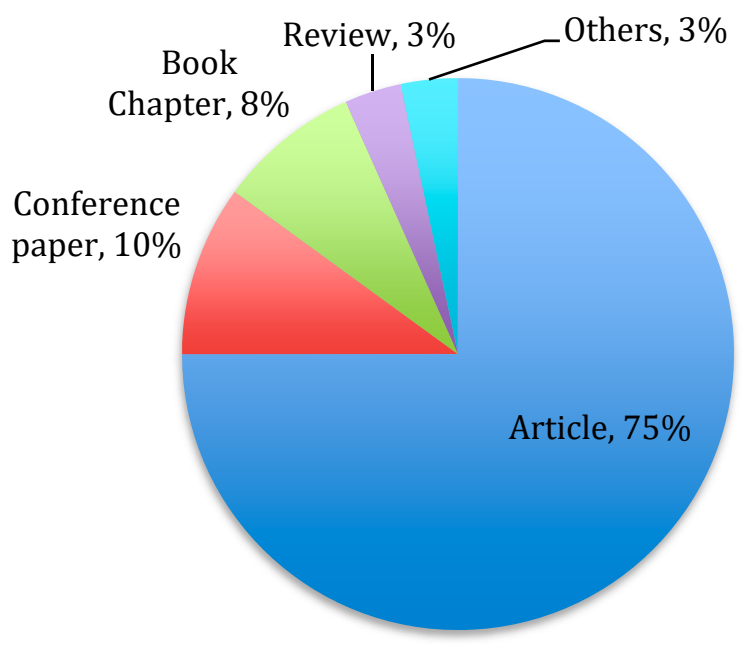

Figure 4. Publications by type of document.

Figure 5 displays the main subject areas of EI-ISC studies. We can see that $25.6 \%$ of the publications were from Business, Management, and Accounting, followed by Environmental Sciences at 23\% and Social Sciences at 15.7\%. The areas of Energy and Economics make up the remainder with figures of almost $10 \%$ each.

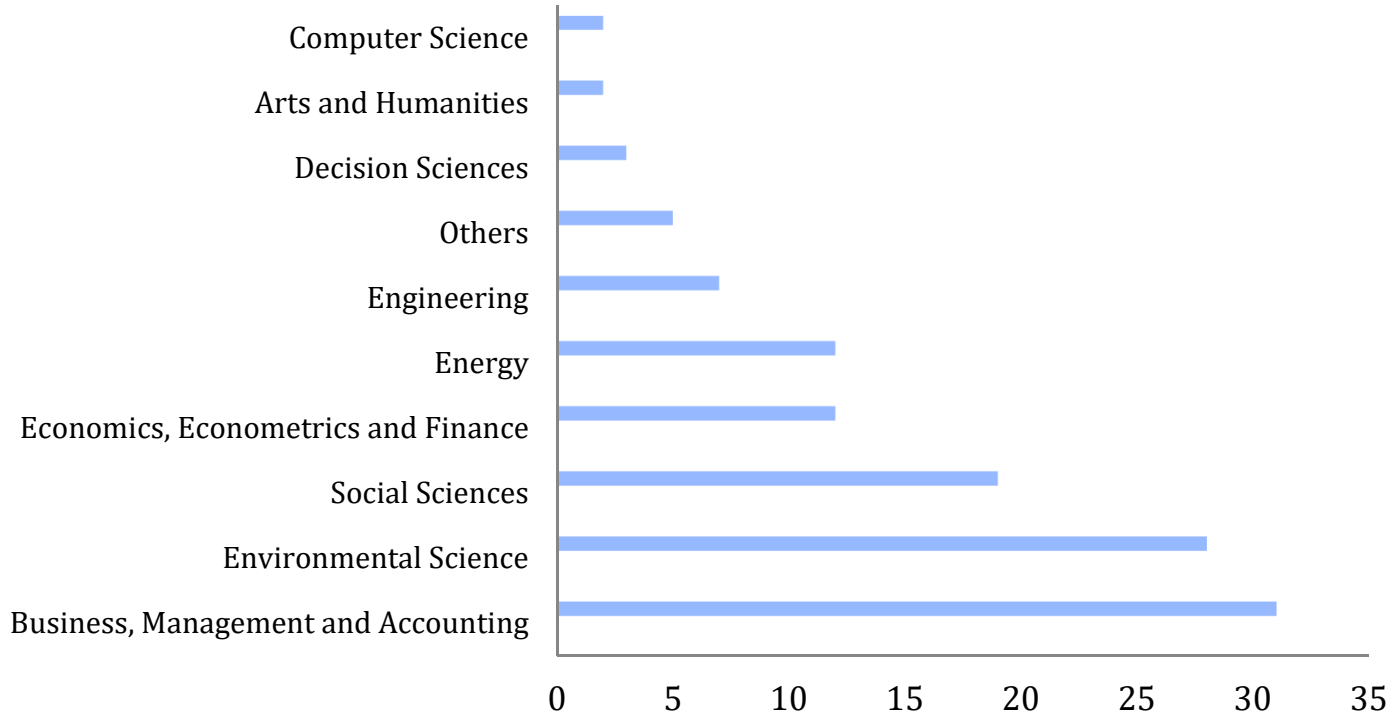

Figure 5. Number of publications by subject area.

Figure 6 shows great diversity in terms of the countries interested in researching the EI-ISC relationship. Most of the studies are from Italy $(18 \%)$, followed by the United States of America (USA) (11\%), China (9\%), and Spain (9\%), together making up almost $50 \%$ of the total. This is mainly due to the great concern about world pollution that has arisen in recent years as a consequence of population growth in certain areas and an increase in the industrial sector to deal with internationalization. According to the BP Statistical Review of World Energy [66], the ranking of the most polluting countries is headed by China at $28.1 \%$, then the USA at $15.2 \%$, and finally the European Union (EU) at $10.3 \%$. 


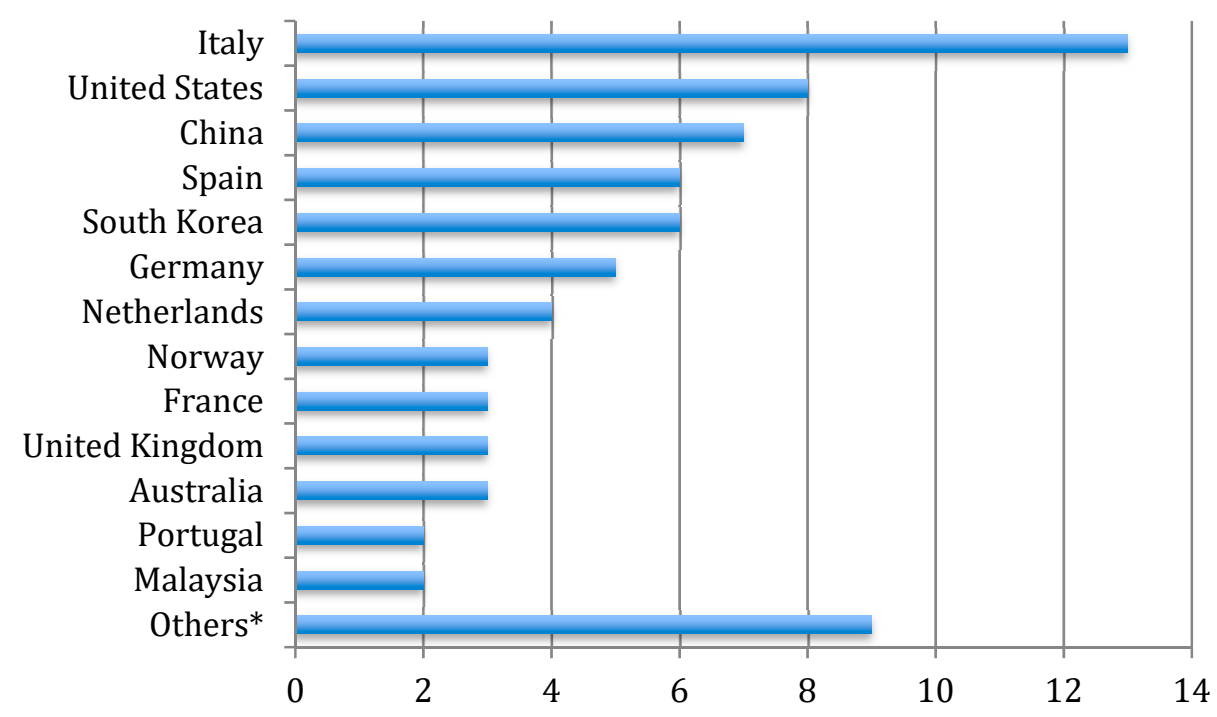

Figure 6. Number of publications by country. ${ }^{*}$ Others: Includes countries with only one publication: Canada, Brazil, Cyprus, Finland, Japan, Kenya, Slovenia, Taiwan, and United Arab Emirates.

Most of the EI-ISC investigations have been carried out only analyzing one country, although the studies carried out at EU level, mainly by Norway, Germany, and Italy stand out, together with those from the OECD countries carried out South Korea and the USA.

Table 1 shows the EI-ISC publications by country, making a further distinction in terms of micro (companies) or macro (country/region) analysis. It can be seen that studies at a macro level represent $44.6 \%$ of the total and at micro level, $55.4 \%$, of which more than $53 \%$ have been carried out by authors belonging to the EU. However, there is no direct relationship between location and level of study, nor is there a time horizon.

Table 1. Publications by country and at a micro or macro level.

\begin{tabular}{|c|c|c|c|c|}
\hline Countries & Total & Micro Level & Macro Level & Authors \\
\hline Portugal & 2 & 2 & 0 & Conceicao et al. [67]; Muñoz-Pascual [11] \\
\hline Malaysia & 2 & 2 & 0 & Keshminder \& Chandran [52]; Keshminder \& del Río [10]; \\
\hline United Kingdom & 3 & 0 & 3 & Matten \& Moon [68]; Ford [69]; Raman \& Mohr [70] \\
\hline Norway & 3 & 1 & 2 & Midttun \& Koefoed [71]; Greaker [72]; Greaker \& Rosendahl [73] \\
\hline France & 3 & 2 & 1 & Labella et al. [74]; Horbach \& Jacob [3]; Costantini [6] \\
\hline Australia & 3 & 1 & 2 & Fradley \& Rashing [75]; Galbreat [2] \\
\hline Netherlands & 4 & 3 & 1 & $\begin{array}{l}\text { Grin et al. [76]; Lacerda \& Van den Bergh [43]; Oyake-Ombis et al. [77]; Jin \& } \\
\text { Scheepens [78] }\end{array}$ \\
\hline Germany & 5 & 1 & 4 & $\begin{array}{c}\text { Beise \& Rennings [79]; Knackfuss [80]; Köhler et al. [81]; Walz \& Köhler [82]; } \\
\text { Horbach \& Jacob [3] }\end{array}$ \\
\hline Spain & 6 & 6 & 0 & $\begin{array}{c}\text { Alfranca [83]; Lacerda \& Van den Bergh [43]; Labella et al. [74]; Triguero et al. [23]; } \\
\text { Keshminder \& del Río [10]; Muñoz-Pascual [11] }\end{array}$ \\
\hline South Korea & 6 & 4 & 2 & Hwang \& Kim [14]; Joo \& Suh [84]; Zhu et al. [85]; Choi \& Yi [7]; Joo et al. [8] \\
\hline China & 7 & 3 & 4 & $\begin{array}{l}\text { Ju et al. [86]; Ju et al. [87]; Tsai et al. [88]; Zhu et al. [85]; Song et al. [4]; Ouyang \& } \\
\text { You [25]; Salman et al. [89] }\end{array}$ \\
\hline United States & 8 & 5 & 3 & $\begin{array}{l}\text { Lanjouw \& Mody [65]; Placet et al. [90]; Atanus [91]; Conceicao et al. [67]; } \\
\text { Loucanová et al. [92]; Joo et al. [8]; Awan \& Sroufe [40]; Brunel [9] }\end{array}$ \\
\hline Italy & 13 & 7 & 6 & $\begin{array}{c}\text { Chiarvesio et al. [93]; Belussi \& Sedita [94]; Costantini \& Mazzanti [95]; Daddi } \\
\text { et al. [42]; Foresti \& Trenti [96]; Tessitore et al. [97]; Cariola et al. [98]; Chiarvesio } \\
\text { et al. [41]; Rubashkina et al. [99]; Dangelico [100]; Capodaglio [101]; Bertarelli \& } \\
\text { Lodi [5]; Costantini [6] }\end{array}$ \\
\hline Others * & 9 & 4 & 5 & $\begin{array}{c}\text { Beise \& Rennings [79]; Matten \& Moon [68]; Oyake-Ombis et al. [77]; Romih \& } \\
\text { Oplotnik [102]; Ghazal et at. [103]; Tsai et al. [88]; Palma et al. [39]; Awan \& } \\
\text { Sroufe [40]; Fethi \& Rahuma [24] }\end{array}$ \\
\hline
\end{tabular}

* Others: includes countries with only one publication: Canada, Brazil, Cyprus, Finland, Japan, Kenya, Slovenia, Taiwan, and United Arab Emirates. 
Few EI-ISC studies have been explicitly based on specific economic theories, the most important of which are: (i) Resource-based theory, in which Triguero et al. [23] state that own resources (age, size, R\&D, and exports) and capabilities (EI) play a fundamental role in explaining innovative performance of the firm and study the link between them. (ii) Contingency theory, in which Tsai et al. [88] echo the suggestion of Dangelico [100], who argues that EI research can use this theory to link the market (export demand and destination), with environmental policy (regulations and aid) and for the innovation capacity that characterizes environmental sustainability. (iii) Transition theory and a multilevel perspective on transitions, in which Oyake-Ombis et al. [77] distinguish three levels to analyze and explain the changes in socio-technical systems (systems for transport, energy, water, and food) and study such changes in urban Kenya, focusing on a conventional solid waste management system or a plastic production system. (iv) The theory of ecological modernization, used by Joo et al. [8] to indicate that government intervention (financial support for environmental certification, environmental R\&D, and environmental training for export companies) is necessary to improve the performance of the Company in the global market and will bring both environmental and economic benefits. (v) Social role theory, used by Horbach and Jacob [3], which attaches importance to the gender of the management team and other staff in the firm, especially regarding female leadership style that could lead to the enhancement of EI. (vi) Finally, institutional theory, applied by Galbreath [2], suggests that women leaders are more likely than leaders who are men to respond to certain social expectations, strengthening the relationship between export intensity and the implementation of green innovations.

At a macro level, research focusing on the effects of international supply chains on the environment points out the existence of two commonly accepted hypotheses $[8,51,104]$ : (i) That regions with a relatively flexible/strict environmental policy tend to specialize in industries with high/low pollution production and commercialization, referred to as pollution haven hypothesis, which may lead to the relocation of export companies to countries with less strict environmental regulations ("pollution havens") in order to reduce their production costs; (ii) the other hypothesis, called the factor endowment hypothesis, considers that environmental policy has a general effect on standard factors, generating differences in resource endowment or technology, thus determining export and commercialization activity in general. This forms the basis of the argument for what is called the 'Porter hypothesis' $[6,105]$. In relation to the latter, several studies provide some estimates concerning the effects of environmental factors on trade competitiveness $[26,104,106]$. Other work in this area, however, shows that export activity in a competitive model can lead to contradictory impacts on the natural environment, on the one hand increasing pollution and, on the other, motivating export companies to reduce it $[107,108]$. The direction and magnitude of these effects depend on the changes prompted by export activity in production models, the state of the natural environment, and also the regulations and policies established to preserve and improve environmental quality [109-111]. From a methodological point of view, in recent literature, the estimation of the impact of international supply chains and economic growth on the environment has been analyzed through a system of relationships depicted by the "Environmental Kuznets curve" [112-114]. Both Anouliès [115] and Cherniwchan [116]; are working on a theoretical model to break down the impact of international supply chains on pollution. They consider the following: A "scale effect", by which the expansion of economic activity negatively affects the environment; a "technical effect", by which economic improvement gives rise to stricter environmental regulations; and a "compound effect", by which specialization and resource efficiency benefit the environment $[117,118]$.

\subsection{Micro or Business Level Analysis}

Of the total number of publications analyzed at a micro level, $81 \%$ use a quantitative methodology, with data taken mostly through business surveys. Only $19 \%$ of the studies are of a qualitative nature, with the following ones standing out: Two agrifood studies on 
Kenya with local players $[77,94]$; a multi-country study on renewable energy in Finland, Sweden, and Denmark [71]; another in Italy on technology companies [5]; and one in Vietnam on the sustainable furniture sector where a showroom was used [78].

Table 2 shows a chronological summary of the EI-ISC interrelationships found, taking into account the years and sector of activity, and then linking them to the country of origin, differentiating between studies in which: (i) EI is influenced by ISC; (ii) EI influences ISC; (iii) no interrelationship between either variable is found or the results are inconclusive.

Table 2. Interrelationships found in the micro eco-innovation and international supply chains (EI-ISC) studies.

\begin{tabular}{|c|c|c|c|}
\hline Author (Year) & Country & Sector & Relation (+/-) \\
\hline \multicolumn{4}{|c|}{ Studies in which international supply chain influence eco-innovation } \\
\hline Atanus [91] & USA & - & $(+)$ \\
\hline Alfranca [83] & Spain & Industry & $(+)$ \\
\hline Chiarvesio et al. [41] & Italy & Multisectoral & $(-)$ \\
\hline Galbreath [2] & Australia & Agrifood & $(+)$ \\
\hline Triguero et al. [23] & Spain & Industry & $(+)$ \\
\hline Choi \& Yi [7] & South Korea & Industry & $(+)$ \\
\hline Horbach \& Jacob [3] & France/Germany & Services & $(+)$ \\
\hline Awan \& Sroufe [40] & Finland/USA & Industry & $(+)$ \\
\hline Keshminder \& del Río [10] & Malaysia/Spain & Industry & $(+)$ \\
\hline Muñoz-Pascual [11] & Portugal/Spain & Multisectoral & $(+)$ \\
\hline \multicolumn{4}{|c|}{ Studies in which eco-innovation influences international supply chain } \\
\hline Midttun \& Koefoed [71] & Norway & Energy & $(+)$ \\
\hline Conceicao et al. [67] & USA & Industry & $(+)$ \\
\hline Chiarvesio et al. [93] & Italy & Industry & $(+)$ \\
\hline Costantini \& Mazzanti [95] & Portugal/Italy & Industry & $(+)$ \\
\hline Daddi et al. [42] & Italy & Multisectoral & $(+)$ \\
\hline $\begin{array}{l}\text { Lacerda \& Van den } \\
\text { Bergh [43] }\end{array}$ & The Netherlands/Spain & Technology & $(+)$ \\
\hline Jin \& Scheepens [78] & The Netherlands & Industry & $(+)$ \\
\hline Loucanová et al. [92] & USA & Packaging & $(+)$ \\
\hline Joo \& Suh [84] & South Korea & Multisectoral & $(+)$ \\
\hline Labella et al. [74] & France/Spain & Agrifood & $(+)$ \\
\hline Tsai et al. [88] & Taiwan/China & Industry & $(+)$ \\
\hline Zhu et al. [85] & China/South Korea & Industry & $(+)$ \\
\hline Palma et al. [39] & Brazil & Industry & $(+)$ \\
\hline Song et al. [4] & China & Industry & $(+)$ \\
\hline Joo et al. [8] & South Korea/USA & Industry & $(+)$ \\
\hline Bertarelli \& Lodi [5] & Italy & Technology & $(+)$ \\
\hline \multicolumn{4}{|c|}{ Studies in which there is no (NR) relationship or it is inconclusive (IC) } \\
\hline Belussi \& Sedita [94] & Italy & Agrifood & IC \\
\hline Tessitore \& Daddi [97] & Italy & Multisectoral & NR \\
\hline Cariola et al. [98] & Italy & Industry & NR \\
\hline Oyake-Ombis et al. [77] & Kenya/The Netherlands & Industry & NR \\
\hline $\begin{array}{l}\text { Keshminder \& } \\
\text { Chandran [52] }\end{array}$ & Malaysia & Industry & NR \\
\hline
\end{tabular}

It can be observed that $52 \%$ of the studies carried out at a micro level focus on the influence of EI on ISC, and all of them show that there is a positive relationship between both variables. In this regard, Bertarelli and Lodi [5] and Costantini and Mazzanti [95] argue that environmental and energy taxes have a positive influence on EI, which in turn influences ISC. Palma et al. [39] and Tsai et al. [88] point out that a high level of social and environmental awareness helps EI to benefit ISC.

Thus, through innovation in biofuels, renewable energy, sustainable products, and greener processes, companies are able to increase their export levels $[43,71,74,78]$. Addi- 
tionally, the development of EI and its enhancement of ISC is positively associated with company size and network cooperation among companies [67].

In contrast, $32 \%$ analyzed the influence of ISC on IE, highlighting an equally positive relationship. As a result, Alfranca [83] concludes that the increase in $\mathrm{CO}_{2}$ emissions influences high-tech exports and this in turn influences EI. Awan and Sroufe [40] recommend that export companies focusing on EI should direct their collaborative efforts towards improving social performance of its employees through good health, since improved innovation is directly linked to better social performance. Atanus [91] considers that the companies that are part of ISC should take it upon themselves to comply with all the environmental legislation restrictions on hazardous substances, through technological development and environmental innovations. According to Choi and Yi [7], companies engaged in intensive export activities are committed to EI, although they find that they are not entirely effective in generating environmental product innovations. Galbreath [2] and Horbach and Jacob [3] add that export intensity is positively correlated to EI, especially when women are business leaders because they are more environmentally aware in innovative decision-making.

For Keshminder and del Rio [10], ISC has an impact on EI through environmental strategies, since it plays a key mediating role, acting both directly and indirectly with other variables different to EI (e.g., environmental knowledge, consumer pressure, and ecological skills), regardless of the country's level of development. Additionally, Triguero et al. [23] point out that ISC, R\&D, and company size and age have a positive influence on EI and the level of employment. Belonging to a multinational group reinforces environmental proactivity in EI as well as collaboration. Thus, the more internationalized the production value chain, the greater the likelihood of investing in environmentally friendly processes or products. Only Chiarvesio et al. [41] find a negative correlation between ISC and EI, as foreign markets have lower environmental standards than local markets.

Finally, $13 \%$ of the micro studies do not find any type of relationship and only one is inconclusive. Furthermore, country, sector, and date are not seen to be relevant factors influencing the type of relationship established.

\subsection{Macro or Country Level Analysis}

Table 3 provides a chronological summary of the main results found in the EI-ISC studies carried out at a macro level, taking into account the year, country, and direction in which the variables studied are related.

It should be noted that $55 \%$ of the studies carried out at a macro level study the influence of EI on ISC, and all of them show that there is a positive relationship. In this regard, Placet et al. [100] conclude that EI helps to promote economic improvement and Romih and Oplotnik [102] consider EI to be a source of opportunities for exports through cooperation. As such, competitiveness increases through ISC when EI is introduced [6], either in renewable energies [9], air pollution abatement [119], water treatment [75], smart plugs [103], or biofuel production [81]. Apart from that, the tax system, financial incentives, [80], a strict environmental policy [72], and also national regulation and spending on pollution control protecting the market [65] with sufficient EI to reduce pollution will all help with exports to other countries.

The region where this correlation is most analyzed is the EU, followed by the USA and Asia. As such, it can be observed that there is growing environmental concern in Europe regarding how both eco-innovations and environmental policies related to regulations and subsidies affect international competitiveness $[6,9,25,65,81]$. In this regard, Placet et al. [90] confirm the positive influence of government environmental policies on increasing competitiveness and economic performance, through innovation in techniques that reduce pollution and energy consumption. Furthermore, it points out that companies can improve their environmental performance, but only when they collaborate and maintain a relationship of trust with clients. Romih and Oplotnik [102] also sees EI as a source of opportunities for internationalization through cooperation. 
Table 3. Interrelationships found in the macro EI-ISC studies.

\begin{tabular}{|c|c|c|}
\hline Author (Year) & Country & Relation (+/-) \\
\hline \multicolumn{3}{|c|}{ Studies in which international supply chain influence eco-innovation } \\
\hline Beise \& Rennings [79] & Japan/Germany & $(+)$ \\
\hline Ju et al. [86] & China & $(+)$ \\
\hline Ju et al. [87] & China & $(+)$ \\
\hline Walz \& Köhler [82] & Germany & $(+)$ \\
\hline Rubashkina et al. [99] & Italy & $(+)$ \\
\hline Dangelico [100] & Italy & $(+)$ \\
\hline Fethi [24] & Cyprus & $(+)$ \\
\hline \multicolumn{3}{|c|}{ Studies in which eco-innovation influences international supply chain } \\
\hline Lanjouw \& Mody [65] & USA & $(+)$ \\
\hline Placet et al. [90] & USA & $(+)$ \\
\hline Greaker [72] & Norway & $(+)$ \\
\hline Orsato [60] & Australia & $(+)$ \\
\hline Knackfuss [80] & Germany & $(+)$ \\
\hline Ford [69] & UK & $(+)$ \\
\hline Foresti \& Trenti [96] & Italy & $(+)$ \\
\hline Fradley \& Rampersad [75] & Austria & $(+)$ \\
\hline Köhler et al. [81] & Germany & $(+)$ \\
\hline Romih \& Oplotnik [102] & Slovenia & $(+)$ \\
\hline Ghazal. et al. [103] & UAE & $(+)$ \\
\hline Hwang \& Kim [14] & South Korea & $(+)$ \\
\hline Sung [120] & South Korea & $(+)$ \\
\hline Brunel [9] & USA & $(+)$ \\
\hline Costantini [6] & France/Italy & $(+)$ \\
\hline Ouyang \& You [25] & China & $(+)$ \\
\hline \multicolumn{3}{|c|}{ Studies in which there is no (NR) relationship or it is inconclusive (IC) } \\
\hline Greaker \& Rosendahl [73] & Norway & NR \\
\hline Matten \& Moon [68] & Canada/UK & IC \\
\hline Grin et al. [76] & The Netherlands & IC \\
\hline Raman \& Mohr [70] & UK & IC \\
\hline Capodaglio [101] & Italy & IC \\
\hline Salman et al. [89] & China & IC \\
\hline
\end{tabular}

On the other hand, $24 \%$ of the studies analyze the influence of ISC on EI. All of them are located in Asia and Europe and obtain positive correlations, confirming that international trade has a positive effect on EI [99]. This positive relationship is enhanced by the role of environmental policies and regulations $[79,82,87]$. Thus, for Beise and Rennings [79], environmental regulations generate export opportunities for the pioneering country, stimulating in turn the generation and adoption of EI. For Ju et al. [87], however, the pressure of regulation does not behave in the same way from one country to another, as is the case of China.

Finally, $20 \%$ of the macro studies do not obtain conclusive results, and even one does not find any kind of relationship whatsoever.

\section{Eco-Innovation and Exports in International Agrifood Supply Chains}

There is great diversity in the sectors of activity that have been studied at micro level (Figure 7). The industrial or manufacturing sector stands out at 52\%, with the agrifood sector and the multisectoral sector lagging far behind at 13\% each. The technology and energy sectors are even less important at 6 and $7 \%$ respectively, even though the petroleum companies are the most polluting ones in the world [121].

It is surprising how few publications have been released on the agrifood sector, despite the fact that most agrifood supply chains have a great impact on the environment during the different phases of their life cycle and food consumption are possibly some of the most significant drivers of environmental burdens [122]. This is reflected in various studies and 
reports. For example, the European Science and Technology Observatory [123] points out that there are three areas that have the greatest impact: Food and beverages, private transport, and housing. Together, they are responsible for $70-80 \%$ of the environmental impact caused by consumption and represent around $60 \%$ of consumer spending. According to Tukker et al. [124], the food and beverage sector represents $20-30 \%$ of the environmental impact resulting from private consumption. In addition, the food industry has a negative impact on the environment in terms of energy use, $\mathrm{CO}_{2}$, and hazardous waste, among others, making up $64 \%$ of European industrial pollution. For all these reasons, studies should be encouraged to find out if measures are being taken to promote EI by agrifood companies and how this affects their competitiveness and profitability (e.g., García-Granero et al. [125]). This is why a specific section is dedicated to analyze the EI-ISC studies in this sector, which considers the differences that may exist with other sectors due to the particular characteristics it possesses (basic products, social implications, and healthiness of the population, among others).



Figure 7. Micro EI-ISC studies by sector. ${ }^{*}$ na: Non-available.

Global population growth and changing eating habits are putting upward pressure on food demand [121]. As a result, production is becoming increasingly globalized and industrialized, leading to standardization. Agricultural practices, especially in developed countries, have been intensified to increase area yield as much as possible. In addition, new production practices are being implemented that encourage improved levels of food safety, such as biological control and the implementation of traceability [126]. In this regard, Galdeano-Gómez et al. [127] show how through biological control, the use of fertilizers and plant protection products is minimized in order to promote sustainability in Spanish agricultural production. Accordingly, environmental sustainability is closely linked to biological control, since the latter is analogous to a high level of pest control [128].

On the other hand, globalization has led to an increasing loss of local markets, with a consequent growth in transport distances between growers, industry, and consumers, inevitably incurring greater social and environmental costs [122,129]. Agrifood trade has shown a significant increase, growing by 3.1\% per year and rising by 36\% from 2008 to 2018 . As part of this, the European Union, USA, and China are the top 10 exporters of agricultural products [130]. As a result, the search for sustainable production and consumption in the agrifood sector has triggered the creation of many international initiatives and strategies designed to reduce environmental impact and hence obliges companies to increase their productivity and export capacity through EI processes.

Regarding supply chains in the fresh agrifood sector, there is a tendency to design short supply chains (SSCs) [131]. These chains are characterized by the existence of a more direct relationship between producer and consumer, a reduced number of interme- 
diaries, and the minimization of transport, as the product is produced in the same area where it is consumed (proximity sales), thereby creating notable local economic and social benefits [132]. However, some research (e.g., Cagliano et al. [133]) call into question the sustainability, especially the economic one, of the SSCs. On the other hand, despite not being so common, short proximity chains (SPCs), associated with the sale of very specific products, also exist. Nevertheless, some research has also questioned the role of this type of chains in decreasing environmental impact and improving local development [134].

From a different approach, the term "short", rather than referring to spatial proximity, could mean correctly communicating to the consumer information regarding systems of production and their location [135]. These short chains are called "spatially extended short chains" (SESCs). In general, SESCs can represent a solution for retailers commercializing perishable products, since supply networks are more difficult to manage in these cases. In this context, eco-innovation might well help the SESCs be recognized and valued by consumers, since they represent an important source of innovation in agrifood chains organization and can become even more sustainable than the traditional SSCs [136]. Within the observed heterogeneity, most agrifood supply-chain eco-innovations are focused on products or processes, such as cleaner technologies, energy efficiency, and renewable energies [137,138]; better managing flows of materials and other resources [139,140]; greener inputs and raw materials [140,141]; food waste levels [138,142]; and recycling [143]. Other EIs are included in the organizational dimension, like enhanced greener networks and inter-organizational cooperation and interactions [144,145], sharing normative and interpretive schemes [139], environmental management orientation, sustainability concerned staff and involving environmental experts [146]. Finally, eco-labels and quality certifications also stand out [147]. When there is an effective channel leader with influence over the other actors, eco-innovation can diffuse from company to company as a result of enhanced collaboration [148].

Unsurprisingly then, numerous authors agree that EI has a positive impact on food exporting companies $[107,149,150]$. Other studies in this sector have found EI to positively influence ISC. This is the case for Daddi et al. [42] on ham production in Italy. The sensitivity of local companies to environmental issues has been enhanced by service centers that provide information and training on environmental legislation and technological eco-innovation. With regard to EI, there is a joint water purification and waste treatment plant, while the relevant authorities have established initiatives to promote cooperative waste separation and environmental awareness policies. There is also a positive correlation between EI and the ability to safeguard employment. In terms of exports, they increased by more than $9 \%$ compared to the previous year. By looking at the link between the levels of EI and ISC, it is apparent that some foreign markets may have taken notice of the environmental initiatives and rewarded them by increasing their orders. EI can consequently strengthen companies' resilience and environmental excellence, as well as their internalization.

Along the same lines, Labella et al. [74] explore the degree of environmental involvement of olive oil producers in Andalusia (Spain), which confirms that despite the need to adopt EI being due to the requirements of foreign markets, the companies surprisingly only make a limited voluntary environmental commitment. However, the increase in administrative requirements and periodic audits makes the following necessary: Investments, a period of adjustment in the organization, and involvement of all the members. All this would mean being able to access the international market in a competitive way, with better product differentiation, at the same time increasing exports, profitability, and cost reduction, as well as improving the image and reputation of the organization.

On the other hand, there are also studies in this sector that have found a way in which ISC to positively influence EI. One such example, according to Galbreath [2] and WFA [149], is that of Australian wine exporters, who are under considerable pressure from retailers in the UK and US markets to demonstrate environmentally sound business practices and production processes $[150,151]$. The results suggest that as companies 
intensify their exports, they tend to implement EI at a faster pace as well. In addition, it highlights that the existence of women in leadership roles in companies further enhances this positive relationship.

However, there are also studies that have not obtained conclusive results regarding the ISC-El interrelationship in this sector. For example, Belussi and Sedita [94] dealt with cut flowers in Kenya, exported in the main to Europe, and analyzed the application of international scientific innovations and their dissemination among local companies, thus leading to the introduction of eco-innovations.

In general, the improvement of the different agrifood supply chains can be given by the implementation of eco-innovations, not only in products or processes $[139,140]$, but also in the organization and environmental management orientation [146]. In addition, environmental concern at management and staff level tends to promote greener networks and eco-innovative agrifood supply chains [131]. Nevertheless, there is a need for greater research that delves deeper into the ISC-EI interrelationship in the agrifood sector, providing empirical evidence for the most important factors and variables, because of their environmental and social implications as essential goods.

\section{Conclusions and Future Research Directions}

In recent years, environmental performance at both micro and macro levels has become a priority not only for the world's major polluting countries but also those with greater environmental awareness and sensitivity. This has led researchers to study how innovations carried out in companies at an environmental level affect their exporting and internalization processes and vice versa. The main goals of our study are to provide a literature review of the progress and current status of world research on EI-ISC, which, to our knowledge, has not yet been carried out, together with an analysis of the directions of causation between these variables and the most influential factors, with particular reference to the agrifood sector.

In general, it can be seen that there has been a great deal of interest in the subject over the last five years, which is the period containing the majority of studies $(63.3 \%$ of the total). The vast majority of the documents $(82 \%)$ show that there is a positive EIISC interrelationship, with EI having a greater influence on ISC. It has also become clear that concern for the implementation of innovative actions that strive for environmental sustainability in an international setting is a problem that is felt both at a regional or macro level and at a business or micro level. ISC-EI studies at a macro level represent $44.6 \%$ of the total and at micro level $55.4 \%$.

The country is not a determining factor in the EI-ISC relationship. In fact, no behavioral pattern has been found that governs the type of relationship according to the country as a subject of study. A wide variety of countries have been investigated with respect to these interrelations. The majority point to Italy at $18 \%$, followed by the USA at $11 \%$, China at $9 \%$, and Spain at $9 \%$. It should also be noted that $53 \%$ of the publications have been written by authors belonging to the EU. Additionally, the USA and South Korea have mainly focused on studying the influence of EI on ISC, whereas the Netherlands, Asia, and Brazil prefer studies in both directions at a micro level.

At a macro level, over $55 \%$ of documents explores the influence of EI on ISC, while just $24 \%$ deals with the influence of ISC on EI. All of them find a positive relationship. Among the main findings, the role of environmental policies and regulations as promoters of the ISC-EI relationship stands out. This eases the work of policy makers as environmental regulations have traditionally been considered detrimental to international competitiveness, but recent research confirms that they have a very positive effect on international competitiveness through EI. This finding may encourage the implementation of such policies, without having to devote so much energy towards arguing the case for implementation beyond pure environmental protection. In addition, competitiveness increases through exports when exporting companies try to meet foreign market demands for sustainability, i.e., when EI is employed in renewable energies, air decontamination, water treatment, or 
biofuel production, as the use of clean energy promotes greater acceptance by customers in other environmentally friendly countries. Furthermore, collaborative strategies, the tax system, financial incentives, strict environmental policy, national regulation, and spending on pollution control and market protection, with adequate EI to reduce pollution, will help increase exports to other countries. Additionally, EI is found to help the company to improve financially and it is also a source of opportunities for exports. Thus, governments should establish stricter environmental regulations and/or increase the number of industries to which they can be applied so as to encourage more EI, at the same time making it more effective.

At a micro level, most of the studies (53\%) analyze the influence of EI on ISC and all of them show that there is a positive relationship. Indeed, only one shows a negative effect. Our results offer interesting information on the relationship between the internationalization of a company and its environmental attitude both from the point of view of the international production value chain and from the point of view of knowledge. Company size and cooperating strategies are found to be key factors influencing EI-ISC. Cooperating helps companies to better develop their EI processes and has both commercial and political implications. In this regard, a large company will probably be able to better govern its processes and easily collaborate both nationally and internationally with other players in the value chain (suppliers, distributors, and customers). On the other hand, small companies have fewer opportunities to collaborating and becoming a member of an international group to access resources with external knowledge.

There is a great diversity of sectors of activity that have been studied, and, in all of them, a positive relationship between EI and ISC is found, meaning it is not a key variable. The industrial/manufacturing sector standing out at $52 \%$, with the agrifood and multi sectors lagging far behind at $13 \%$ each. It is surprising not to have found more publications on agrifood EI-ISC since it is among those with the greatest need of being analyzed due to its social and environmental influence on the demand for unskilled labor, the need to save water in view of the scarcity of available water resources, the growing contamination of aquifers, and high energy consumption, among others. Additionally, agrifood EI can be considered essential for the transition to sustainability and the achievement of food safety in ISC. Greener production and processes should be accompanied by organisational and commercial eco-innovations as a way of mitigating environmental externalities of agriculture and subsequent related international food crises, from a multidimensional approach. In line with the above, it is necessary to implement new green practices that encourage the improvement of food safety and sustainability levels in the entire supply chain. The predominant factors might be market regulations; promotion of EI in different areas (products, processes, planning, technology and R\&D); cooperation with the parties involved in the effective implementation of EI; the environmental attitudes, perceptions and intentions of decision makers; environmental concern at management and staff level; and the implementation of greener organisational business models. Accordingly, as these are essential goods, studies in this area should be stepped up because of the implications, not only for the environment but also for society.

In summary, several factors can influence the positive ISC-EI interrelationship, including $\mathrm{CO}_{2}$ emissions, energy taxation, social performance, environmental regulation, cooperation, leadership role of women, employment level, business size, or even focusing EI on biofuels, renewable energy, and sustainable products. Therefore, efforts at a macro or regional level should be geared towards greater environmental awareness, the implementation of preventive measures, increased regulation, and sanctions for those who fail to comply, and finally government backing for achievement of the goals set. At a micro level, EI can be a source of opportunities for companies and exports through collaboration among supply chain members. A change of mentality is required in a way that sustainability should take precedence over excessive economic growth by implementing good eco-innovative processes that help companies solve existing problems, improve their image in the eyes of national and international clients, and also help them increase their prof- 
itability and competitiveness as part of a global positioning strategy. In addition, leaders within companies influence strategy and culture, expand and refine product development and processes, and also determine levels of strategic action, including those related to EI. As such, decision-makers within the company can strengthen or weaken the relationship between external pressures from export markets and EI, which is why their role is considered a key element to be addressed. Regarding administrations, they should promote the adoption of EIs and the cooperation between companies in entering new sustainable markets, as important success factors.

Nevertheless, this study is not without its limitations, which could serve as encouragement for future work. One of them is that most studies analyze the variables separately, while in others mixed and inconsistent results are obtained, meaning sometimes the interrelationships between the variables and the factors that influence them are not clear. Although much progress has been made, we deem it necessary to continue researching this topic because of the great interest it generates for companies and governments. Apart from that, it only considers the terms export and international supply chains in the search, so future studies could try taking into account a broader concept of internationalization, which includes production relocation to a third country, international transfer of knowhow, and direct investment abroad. It would also be worth considering other variables such as company size, years of service, management style, and profitability, and complement the study with other databases. Finally, the last six years have seen a sizeable increase in the number of publications studying the ISC-EI relationship, so it is clearly an emerging field of research in which to delve deeper for future studies, including environmental plans, especially in sectors other than industry, such as the agrifood supply chains.

Author Contributions: Conceptualization, L.P.-M. and E.G.-G.; methodology, L.P.-M.; formal analysis, M.d.C.G.-Q.; investigation, M.d.C.G.-Q.; resources, M.d.C.G.-Q. and A.C.-O.; data curation, L.P.-M. and E.G.-G.; writing-original draft preparation, M.d.C.G.-Q.; writing-review and editing, M.d.C.G.-Q. and A.C.-O.; supervision, L.P.-M.; funding acquisition, E.G.-G. All authors have read and agreed to the published version of the manuscript.

Funding: This research was partially funded by Spanish MCINN (project $\mathrm{ECO}_{2}$ 017-82347-P) and European Commission (NEFERTITI project No. 772705; LIFE ALCHEMIA project LIFE16 ENV/ES/ 000437). The authors are also grateful for the support received from CEMyRI and EMME project (AMIF/2017/AG/INTE/821726), and TECNOVA.

Institutional Review Board Statement: Not applicable.

Informed Consent Statement: Not applicable.

Data Availability Statement: Not applicable.

Conflicts of Interest: The authors declare no conflict of interest.

\section{References}

1. Ohmae, K. The Borderless World: Power and Strategy in the Unterlinked Economy; Harper Business: New York, NY, USA, 1990; pp. 342-343.

2. Galbreath, J. Drivers of Green Innovations: The Impact of Export Intensity, Women Leaders, and Absorptive Capacity. J. Bus. Ethics 2019, 158, 47-61. [CrossRef]

3. Horbach, J.; Jacob, J. The relevance of personal characteristics and gender diversity for (eco-)innovation activities at the firm-level: Results from a linked employer-employee database in Germany. Bus. Strat. Environ. 2018, 27, 924-934. [CrossRef]

4. Song, M.; Chen, M.; Wang, S. Global supply chain integration, financing restrictions, and green innovation: Analysis based on 222,773 samples. Int. J. Logist. Manag. 2018, 29, 539-554. [CrossRef]

5. Bertarelli, S.; Lodi, C. Heterogeneous firms, exports and Pigouvian pollution tax: Does the abatement technology matter? J. Clean. Prod. 2019, 228, 1099-1110. [CrossRef]

6. Costantini, V.; Crespi, F.; Paglialunga, E.; Sforna, G. System transition and structural change processes in the energy efficiency of residential sector: Evidence from EU countries. Struct. Chang. Econ. Dyn. 2020, 53, 309-329. [CrossRef]

7. Choi, H.; Yi, D. Environmental innovation inertia: Analyzing the business circumstances for environmental process and product innovations. Bus. Strat. Environ. 2018, 27, 1623-1634. [CrossRef] 
8. Joo, H.-Y.; Seo, Y.W.; Min, H. Examining the effects of government intervention on the firm's environmental and technological innovation capabilities and export performance. Int. J. Prod. Res. 2018, 56, 6090-6111. [CrossRef]

9. Brunel, C. Green innovation and green Imports:Links between environmental policies, innovation, and production. J. Environ. Manag. 2019, 248, 109290. [CrossRef]

10. Keshminder, J.S.; del Río, P. The missing links? The indirect impacts of drivers on eco-innovation. Corp. Soc. Responsib. Environ. Manag. 2019, 26, 1100-1118. [CrossRef]

11. Muñoz-Pascual, L.; Curado, C.M.M.; Galende, J. The Triple Bottom Line on Sustainable Product Innovation Performance in SMEs: A Mixed Methods Approach. Sustainability 2019, 11, 1689. [CrossRef]

12. Xavier, A.F.; Naveiro, R.M.; Aoussat, A.; Reyes, T. Systematic literature review of eco-innovation models: Opportunities and recommendations for future research. J. Clean. Prod. 2017, 149, 1278-1302. [CrossRef]

13. Copeland, B.R.; Taylor, M.S. Trade, Growth and the Environment. J. Econ. Lit. 2004, 42, 7-71. [CrossRef]

14. Hwang, J.; Kim, Y. Effects of Environmental Regulations on Trade Flow in Manufacturing Sectors: Comparison of Static and Dynamic Effects of Environmental Regulations. Bus. Strat. Environ. 2017, 26, 688-706. [CrossRef]

15. Chiarvesio, M.; de Marchi, V.; di Maria, E. Environmental Innovations and Internationalization: Theory and Practices. Bus. Strat. Environ. 2014, 24, 790-801. [CrossRef]

16. Triguero, A.; Moreno-Mondéjar, L.; Davia, M.A. Drivers of different types of eco-innovation in European SMEs. Ecol. Econ. 2013, 92, 25-33. [CrossRef]

17. García-Granero, E.M.; Piedra-Muñoz, L.; Galdeano-Gómez, E. Eco-innovation measurement: A review of firm performance indicators. J. Clean. Prod. 2018, 191, 304-317. [CrossRef]

18. Etkins, P. Eco-innovation for environmental sustainability: Concepts, progress and policies. Int. Econ. Econ. Policy 2010, 7, 267-290. [CrossRef]

19. Lenssen, G.; van Wassenhove, L.; Pickard, S.; Lenssen, J.-J. Corporate responsibility and the role of business in development. Corp. Gov. Int. J. Bus. Soc. 2012, 12. [CrossRef]

20. Scarpellini, S. Eco-Innovación y Eficiencia Energética en Centros Tecnológicos: Caracterización y Sistemas de Medición Para un Análisis Cualitativo de la Actividad. Ph.D. Thesis, Consejo Económico y Social de Aragón, Saragossa, Spain, 2013.

21. Ayob, A.H.; Freixanet, J. Insights into public export promotion programs in an emerging economy: The case of Malaysian SMEs. Eval. Program Plan. 2014, 46, 38-46. [CrossRef]

22. Karakaya, E.; Hidalgo, A.; Nuur, C. Diffusion of eco-innovations: A review. Renew. Sustain. Energy Rev. 2014, 33, 392-399. [CrossRef]

23. Triguero, A.; Cuerva, M.C.; Aledo, C. Álvarez Environmental Innovation and Employment: Drivers and Synergies. Sustainability 2017, 9, 2057. [CrossRef]

24. Fethi, S.; Rahuma, A. The role of eco-innovation on $\mathrm{CO}_{2}$ emission reduction in an extended version of the environmental Kuznets curve: Evidence from the top 20 refined oil exporting countries. Environ. Sci. Pollut. Res. 2019, 26, 30145-30153. [CrossRef] [PubMed]

25. Ouyang, L.; You, D. Measurement Method of Economic Difference of Export-oriented Green Innovation Economy in Coastal Cities Based on Taier Index. J. Coast. Res. 2019, 93, 817-823. [CrossRef]

26. Martín-Tapia, I.; Aragon-Correa, J.A.; Senise-Barrio, M.E. Being green and export intensity of SMEs: The moderating influence of perceived uncertainty. Ecol. Econ. 2008, 68, 56-67. [CrossRef]

27. Galdeano-Gómez, E. Exporting and Environmental Performance: A Firm-level Productivity Analysis. World Econ. 2010, 33, 60-88. [CrossRef]

28. Symeou, P.C.; Zyglidopoulos, S.; Williamson, P. Internationalization as a driver of the corporate social performance of extractive industry firms. J. World Bus. 2018, 53, 27-38. [CrossRef]

29. FAO. The State of Agricultural Commodity Markets. In Agricultural Trade, Climate Change and Food Security; FAO: Rome, Italy, 2018; Available online: http:/ / www.fao.org/3/I9542EN/i9542en.pdf (accessed on 18 September 2019).

30. Máté-Balogh, J.; Jámbor, A. The Environmental Impacts of Agricultural Trade: A Systematic Literature Review. Sustainability 2020, 12, 1152. [CrossRef]

31. Díaz-García, C.; González-Moreno, Á.; Sáez-Martínez, F.J. Eco-innovation: Insights from a literature review. Innovation 2015, 17, 6-23. [CrossRef]

32. Morioka, S.; de Carvalho, M. A systematic literature review towards a conceptual framework for integrating sustainability performance into business. J. Clean. Prod. 2016, 136, 34-146. [CrossRef]

33. Petticrew, M.; Roberts, H. Systematic Reviews in the Social Sciences: A Practical Guide; Blackwell Publishing: Oxford, UK, 2006; p. 352.

34. Kemp, R.; Pearson, P. Final Report MEI Project about Measuring Eco-Innovation. Deliverable 15 of the Measuring Eco-Innovation (MEI) Project for the European Commission 2007. Available online: http:/ / www.merit.unu.edu/MEI (accessed on 16 March 2020).

35. Schiederig, T.; Tietze, F.; Herstatt, C. Green innovation in technology and innovation management-an exploratory literature review. RED Manag. 2012, 42, 180-192.

36. Reid, A.; Miedzinski, M. Eco-innovation-Final Report for Sectoral Innovation Watch; Final Report to Europe INNOVA Initiative; Technopolis Group: Brussels, Belgium, 2008.

37. Martinez, J.I.; Jarillo, J.C. Coordination Demands of International Strategies. J. Int. Bus. Stud. 1991, 22, 429-444. [CrossRef] 
38. Ortega, A.; Espinosa, J.L. Plan de Internacionalización Empresarial. Manual Práctico. Libros profesionales de Empresa, 1st ed.; ESIC: Pozuelo de Alarcón, Spain, 2015; p. 294.

39. Palma, E.P.; Gomes, C.M.; Kruglianskas, I.; Kneipp, J.M.; da Rosa, L.A.B.; Frizzo, K. Relationship between sustainable strategies and export performance: An analysis of companies in the Brazilian gems and jewelry industry. Environ. Qual. Manag. 2018, 27, 97-106. [CrossRef]

40. Awan, U.; Sroufe, R. Interorganisational collaboration for innovation improvement in manufacturing firms: the mediating role of social performance. Int. J. Innov. Manag. 2019, 24, 2050049. [CrossRef]

41. García-Granero, E.M.; Piedra-Muñoz, L.; Galdeano-Gómez, E. Measuring eco-innovation dimensions: The role of environmental corporate culture and commercial orientation. Res. Policy 2020, 49, 104028. [CrossRef]

42. Tessitore, S.; Daddi, T.; Frey, M. Eco-innovation and competitiveness in industrial clusters. Int. J. Technol. Manag. 2012, 58, 49. [CrossRef]

43. Lacerda, J.S.; Bergh, J.C.V.D. International Diffusion of Renewable Energy Innovations: Lessons from the Lead Markets for Wind Power in China, Germany and USA. Energies 2014, 7, 8236-8263. [CrossRef]

44. Flynn, B.; Huo, B.; Zhao, X. The impact of supply chain integration on performance: A contingency and configuration approach. J. Oper. Manag. 2010, 28, 58-71. [CrossRef]

45. Bhatnagar, K. Customer-Oriented Global Supply Chains: Concepts for Effective Management. Inf. Sci. Ref. 2012, 145-159.

46. Dangelico, R.M.; Pontrandolfo, P. From green product definitions and classifications to the Green Option Matrix. J. Clean. Prod. 2010, 18, 1608-1628. [CrossRef]

47. Rennings, K. Redefining innovation-Eco-innovation research and the contribution from ecological economics. Ecol. Econ. 2000, 32, 319-332. [CrossRef]

48. Kemp, R.; Foxon, T. Typology of eco-innovation. In Deliverable 2 of the Measuring Eco-Innovation (MEI) project for the European Commission; UM-MERIT: Maastricht, The Netherlands, 2007.

49. Carrillo-Hermosilla, J.; González, P.D.R.; Könnölä, T.; del Rio, P. Eco-Innovation: When Sustainability and Competitiveness Shake Hands, 1st ed.; Palgrave Macmillan: London, UK, 2009; pp. 6-27.

50. Halila, F.; Rundquist, J. The development and market success of eco-innovations: A comparative study of eco-innovations and "other" innovations in Sweden. Eur. J. Innov. Manag. 2011, 14, 278-302. [CrossRef]

51. Hojnik, J.; Ruzzier, M. What drives eco-innovation? A review of an emerging literature. Environ. Innov. Soc. Transit. 2016, 19, 31-41. [CrossRef]

52. Keshminder, J.S.; Chandran, V.G.R. Eco-Innovation in the Chemical Manufacturing Firms: Insights for Policy Response; Institutions and Economies (formerly known as International Journal of Institutions and Economies); Faculty of Economics and Admin-istration; University of Malaya: Kuala Lumpur, Malaya, 2017; Volume 9, pp. 21-42.

53. PNUMA. Reunión de Altos Funcionarios Gubernamentales Expertos en Derecho Ambiental Dedicada al Examen de Mitad de Período del Cuarto Programa Para el Desarrollo y Examen Periódico del Derecho Ambiental; (Programa de Montevideo IV); UNEP: Montevideo, Uruguay, 2008.

54. Horbach, J.; Rammer, C.; Rennings, K. Determinants of eco-innovations by type of environmental impact - The role of regu-latory push/pull, technology push and market pull. Ecol. Econ. 2012, 78, 12-122. [CrossRef]

55. Cai, W.; Borlace, S.; Lengaigne, M.; van Rensch, P.; Collins, M.; A Vecchi, G.; Timmermann, A.; Santoso, A.; McPhaden, M.J.; Wu, L.; et al. Increasing frequency of extreme El Niño events due to greenhouse warming. Nat. Clim. Chang. 2014, 4, 111-116. [CrossRef]

56. Bossle, M.B.; de Barcellos, M.D.; Vieira, L.M.; Sauvée, L. The drivers for adoption of eco-innovation. J. Clean. Prod. 2016, 113, 861-872. [CrossRef]

57. Hojnik, J.; Ruzzier, M.; Manolova, T.S. Internationalization and economic performance: The mediating role of eco-innovation. J. Clean. Prod. 2018, 171, 1312-1323. [CrossRef]

58. Ortega, A. La internacionalización de la empresa española y la decisión de exportar como solución a la crisis. Rev. Fac. Cienc. Soc. Jurídicas Elche 2010, 1, 88.

59. Kolk, A.; Mauser, A. The evolution of environmental management: From stage models to performance evaluation. Bus. Strategy Environ. 2002, 11, 14-31. [CrossRef]

60. Orsato, R.J. Sustainability Strategies. When Does it Pay to be Green? Palgrave: New York, NY, USA, 2009.

61. Lee, K.-H.; Kim, J.-W. Integrating suppliers into green product innovation development: An empirical case study in the semi-conductor industry. Bus. Strategy Environ. 2011, 20, 527-538. [CrossRef]

62. Srivastava, S.K. Green supply-chain management: A state-of-the-art literature review. Int. J. Manag. Rev. 2007, 9, 53-80. [CrossRef]

63. Elg, U.; Hultman, J. Retailers' management of corporate social responsibility (CSR) in their supplier relationships-Does practice follow best practice? Int. Rev. Retail. Distrib. Consum. Res. 2011, 21, 445-460. [CrossRef]

64. Seuring, S. Supply chain management for sustainable products-Insights from research applying mixed methodologies. Bus. Strat. Environ. 2010, 20, 471-484. [CrossRef]

65. Lanjouw, J.O.; Mody, A. Innovation and the international diffusion of environmentally responsive technology. Res. Policy 1996, 25, 549-571. [CrossRef]

66. BP Statistical Review of World Energy, 68th ed.; An Unsustainable Path; Springer: London, UK, 2019; Available online: https://www.bp.com/content/dam/bp/business-sites/en/global/corporate/pdfs/energy-economics/statistical-review/bpstats-review-2019-full-report.pdf (accessed on 15 March 2020). 
67. Conceicao, P.; Heitor, M.V.; Vieira, P.S. Are environmental concerns drivers of innovation? Interpreting Portuguese innovation data to foster environmental foresight. Technol. Forecast. Soc. Chang. 2006, 73, 266-276. [CrossRef]

68. Matten, D.; Moon, J. "Implicit201d and "explicit" CSR: A conceptual framework for a comparative understanding of corporate social responsibility. Acad. Manag. Rev. 2008, 33, 404-424. [CrossRef]

69. Ford, J. UK scientists set to lead global eco-innovation centre. Engineer 2012, 297, 2.

70. Raman, S.; Mohr, A. Biofuels and the role of space in sustainable innovation journeys. J. Clean. Prod. 2014, 65, 224-233. [CrossRef]

71. Midttun, A.; Koefoed, A.L. Green Innovation in Nordic Energy Industry: Systemic Contexts and Dynamic Trajectories; Springer: Berlin/Heidelberg, Germany, 2005; pp. 115-136.

72. Greaker, M. Spillovers in the development of new pollution abatement technology: A new look at the Porter-hypothesis. J. Environ. Econ. Manag. 2006, 52, 411-420. [CrossRef]

73. Greaker, M.; Rosendahl, K.E. Environmental policy with upstream pollution abatement technology firms. J. Environ. Econ. Manag. 2008, 56, 246-259. [CrossRef]

74. Labella, R.C.; Fort, F.; Rosa, M.P.; Murgado Armenteros, E. M Determining factors of voluntariness in sustainable environmental innovation (eco-processes) and their certification: Agri-food sector. In Proceedings of the European Conference on Innovation and Entrepreneurship, Paris, France, 21-22 September 2017; ECIE: Paris, France, 2017; pp. 125-132.

75. Fradley, K.; Rampersad, G. Green gems: Leading clean technology innovation networks. In Technology Innovation Leadership in Development: A "Middle East" Perspective; Rampersad, G., Patel, F., Eds.; Nova Science Publishers Inc: London, UK, 2014 ; pp. 59-78.

76. Grin, J.; Rotmans, J.; Schot, J. Transitions to Sustainable Development: New Directions in the Study of Long Term Transformative Change. Monograph; Routledge: Abingdon, UK, 2010; pp. 1-10.

77. Oyake-Ombis, L.; van Vliet, B.J.; Mol, A.P. Managing plastic waste in East Africa: Niche innovations in plastic production and solid waste. Habitat Int. 2015, 48, 188-197. [CrossRef]

78. Jin, S.; Scheepens, A.E. Evaluating the sustainability of Vietnamese products: The potential of 'designed in Vietnam' for Viet-namese vs. Dutch markets. Int. J. Technol. Learn. Innov. Dev. 2016, 8, 70-110. [CrossRef]

79. Beise, M.; Rennings, K. Lead markets and regulation: A framework for analyzing the international diffusion of environmental innovations. Ecol. Econ. 2005, 52, 5-17. [CrossRef]

80. Knackfuss, G. Green innovations for the global water market [Grüne Innovationen für den globalen Wassermarkt]. WasserWirtschaft 2011, 101, 49-51. [CrossRef]

81. Köhler, J.; Walz, R.; Marscheider-Weidemann, F. Eco-Innovation in NICs: Conditions for Export Success with an Application to Biofuels in Transport. J. Environ. Dev. 2014, 23, 133-159. [CrossRef]

82. Walz, R.; Köhler, J. Using lead market factors to assess the potential for a sustainability transition. Environ. Innov. Soc. Transit. 2014, 10, 20-41. [CrossRef]

83. Alfranca, O. Can regulations induce environmental innovations? Int. Pol. Econ. 2010, 8, 157-170.

84. Joo, H.-Y.; Suh, H. The Effects of Government Support on Corporate Performance Hedging against International Environmental Regulation. Sustainability 2017, 9, 1980. [CrossRef]

85. Zhu, Q.; Feng, Y.; Choi, S.B. The role of customer relational governance in environmental and economic performance improvement through green supply chain management. J. Clean. Prod. 2017, 155, 46-53. [CrossRef]

86. Ju, Q.; Frang, Y.P.; Ge, Z.Q. The determinants of environmental innovation: An empirical analysis of China. Entrep. Strategy Innov. Sustain. Dev. 2007, 258-262.

87. Ju, Q.; Feng, T.; Ding, Y. Regulation and Environmental Innovation: Effect and Regional Disparities in China. In Recent Innovations in Computing; Springer: Berlin/Heidelberg, Germany, 2013; pp. 1005-1012.

88. Tsai, K.-H.; Liao, Y.-C. Innovation Capacity and the Implementation of Eco-innovation: Toward a Contingency Perspective. Bus. Strat. Environ. 2017, 26, 1000-1013. [CrossRef]

89. Salman, M.; Long, X.; Dauda, L.; Mensah, C.N.; Muhammad, S. Different impacts of export and import on carbon emissions across 7 ASEAN countries: A panel quantile regression approach. Sci. Total Environ. 2019, 686, 1019-1029. [CrossRef] [PubMed]

90. Placet, M.; Anderson, R.; Fowler, K.M. Strategies for Sustainability. Res. Manag. 2005, 48, 32-41. [CrossRef]

91. Atanus, R. Last Things First. Recycl. Today 2006, 44, 108-114.

92. Loucanová, E.; Kalamárová, M.; Olšiaková, M. The path forward for wood products: A global perspective. In Proceedings of the Scientific Papers 9th International Scientific Conference Wood EMA, Baton Rouge, LA, USA, 5-8 October 2016; pp. 66-69.

93. Chiarvesio, M.; di Maria, E.; Micelli, S. Global Value Chains and Open Networks: The Case of Italian Industrial Districts. Eur. Plan. Stud. 2010, 18, 333-350. [CrossRef]

94. Belussi, F.; Sedita, S.R. Industrial Districts as Open Learning Systems: Combining Emergent and Deliberate Knowledge Structures. Reg. Stud. 2012, 46, 165-184. [CrossRef]

95. Constantini, V.; Mazzanti, M. On the green and innovative side of trade competitiveness? The impact of environmental policies and innovation on eu exports. Res. Policy 2012, 41, 132-153.

96. Foresti, G.; Trenti, S. Environmental Goods Trade and Technology in China; The Chinese Economy: Recent Trends and Policy Issues; Springer: Rome, Italy, 2013; pp. 211-233.

97. Tessitore, S.; Daddi, T.; Iraldo, F. The link between environmental and economic performance: Evidence from some eco-innovative industrial clusters. Int. J. Environ. Sustain. Dev. 2013, 12, 124. [CrossRef] 
98. Cariola, M.; Moiso, V.; Pagliarino, E. A Case of Sustainable Innovation Applied to Textile Industry. In Proceedings of the IAMOT 2015-24th International Association for Management of Technology Conference: Technology, Innovation and Management for Sustainable Growth, Cape Town, South Africa, 8-11 June 2015; pp. 2399-2408.

99. Rubashkina, Y.; Galeotti, M.; Verdolini, E. Environmental regulation and competitiveness. Empirical evidence on the Porter Hypothesis from European manufacturing sectors. Energ. Policy 2015, 83, 288-300. [CrossRef]

100. Dangelico, R.M. Green Product Innovation: Where we are and Where we are Going. Bus. Strat. Environ. 2016, 25, 560-576. [CrossRef]

101. Capodagio, A.G. Integrated, decentralized wastewater management for resource recovery in rural and peri-urban areas. Resources 2017, 6, 22. [CrossRef]

102. Romih, D.; Oplotnik, Z.J. Sustainability as a Source of export Opportunities: The case of Slovenian enterprises. In Proceedings of the 26th International Business Information Management Association Conference-Innovation Management and Sustainable Economic Competitive Advantage: From Regional Development to Global Growth—IBIMA, Madrid, Spain, 11-12 November 2015; pp. 3209-3213.

103. Ghazal, M.; Akmal, M.; Iyanna, S.; Ghoudi, K. Smart plugs: Perceived usefulness and satisfaction: Evidence from United Arab Emirates. Renew. Sustain. Energy Rev. 2016, 55, 1248-1259. [CrossRef]

104. Riker, D. Environmental Performance and U.S. Exports. Int. Trade J. 2013, 27, 325-335. [CrossRef]

105. Porter, M.E.; van der Linde, C. Toward a new conception of the environment- competitiveness relationship. J. Econ. Perspect. 1995, 9, 97-118. [CrossRef]

106. Popp, D.; Newell, R.G.; Jaffe, A. Energy, the Environment and Technological Change, Chapter 21 in Handbook of the Economics of Innovation; Elsevier: Amsterdam, The Netherlands, 2010; Volume 2, pp. 873-937.

107. Cole, M.A.; Elliott, R.J.R.; Shimamoto, K. Globalization, firm-level characteristics and environmental management: A study of Japan. Ecol. Econ. 2006, 59, 312-323. [CrossRef]

108. Ferrara, I.; Missios, P.; Yildiz, H.M. Pollution Havens, Endogenous Environmental Policy and Foreign Direct Investment. South Econ. J. 2014, 82, 257-284. [CrossRef]

109. Jin, W.; Zhang, H.; Liu, S.; Zhang, H. Technological innovation, environmental regulation, and green total factor efficiency of industrial water resources. J. Clean. Prod. 2019, 211, 61-69. [CrossRef]

110. Albrizio, S.; Kozluk, T.; Zipperer, V. Environmental policies and productivity growth: Evidence across industries and firms. J. Environ. Econ. Manag. 2017, 81, 209-226. [CrossRef]

111. Andersson, F.N. International trade and carbon emissions: The role of Chinese institutional and policy reforms. J. Environ. Manag. 2018, 205, 29-39. [CrossRef]

112. Solarin, S.A.; Al-Mulali, U.; Ozturk, I. Validating the environmental Kuznets curve hypothesis in India and China: The role of hydroelectricity consumption. Renew. Sustain. Energy Rev. 2017, 80, 1578-1587. [CrossRef]

113. Ahmed, K.; Rehman, U. What drives carbon dioxide emissions in the long-run? Evidence from selected South Asian Countries. Renew. Sustain. Energ. Rev. 2017, 70, 1142-1153. [CrossRef]

114. Saleem, H.; Khan, M.B.; Shabbir, M.S. The role of financial development, energy demand, and technological change in envi-ronmental sustainability agenda: Evidence from selected Asian countries. Environ. Sci. Pollut. Res. 2020, 27, 1. [CrossRef] [PubMed]

115. Anouliés, L. Are trade integration and the environment in conflict? The decisive role of countries' strategic interactions. Int. Econ. 2016, 148, 1-15. [CrossRef]

116. Cherniwchan, J.; Copeland, B.R.; Taylor, M.S. Trade and the Environment: New Methods, Measurements, and Results. Trade Environ. New Methods Meas. Results 2016, 9, 59-85. [CrossRef]

117. Bajona, C.; Chu, T. Reforming state owned enterprises in China: Effects of WTO accession. Rev. Econ. Dyn. 2010, 13, 800-823. [CrossRef]

118. Hu, J.; Jiang, H.; Holmes, M.J. Government subsidies and corporate investment efficiency: Evidence from China. Emerg. Mark. Rev. 2019, 41, 41. [CrossRef]

119. Griffin, P. The Carbon Majors Database. CDP Carbon Majors Report 2017. CDP Driving Sustainable Economies; Partner Climate Accountabiity Institute: London, UK, 2017.

120. Sung, B.; Yeom, M.-B.; Kim, H.-G. Eco-Efficiency of Government Policy and Exports in the Bioenergy Technology Market. Sustainability 2017, 9, 1549. [CrossRef]

121. Alexandratos, N.; Bruinsma, J. World Agriculture Towards 2030/2050. Global Perspective Studies Team; Agricultural Development Division: Rome, Italy, 2012.

122. Notarnicola, B.; Salomone, R.; Petti, R.; Renzullli, P.A.; Roma, R.; Cerutti, A.K. Life Cycle Assessment in the Agri-Food Sector. Case Studies, Methodological Issues and Best Practices; Rete Italiana LCA, Springer: Cham, Switzerland, 2015; pp. 2-5.

123. Environmental Impact of Products (EIPRO). Analysis of the Life Cycle Environmental Impacts Related to the Final Consumption of the EU-25; Institute for Prospective Technological Studies; European Science and Technology Observatory: Brussels, Belgium, 2006; Available online: https:/ / op.europa.eu/en/publication-detail/-/publication/3b4b06b7-4bc0-4350-a20b-accdc70d1d94/ language-en (accessed on 4 March 2020).

124. Tukker, A.; Huppes, G.; Guinée, J.; Heijungs, R. Analysis of the Life Cycle Environmental Impacts Related to the Total Final Consumption of the eu-25; European commission; Joint Research Centre (JRC); Institute for Prospective Technological Studies (IPTS): Sevilla, Spain, 2006. 
125. García-Granero, E.M.; Piedra-Muñoz, L.; Galdeano-Gómez, E. Multidimensional Assessment of Eco-Innovation Implementation: Evidence from Spanish Agri-Food Sector. Int. J. Environ. Res. Public Health 2020, 17, 1432. [CrossRef]

126. Codex Alimentarius Commission. European Community Positions. 2006. Available online: https://ec.europa.eu/food/sites/ food/files/safety/docs/codex_cac_29_agenda-items_en.pdf (accessed on 15 April 2020).

127. Galdeano-Gómez, E.; Aznar-Sánchez, J.A.; Pérez-Mesa, J.C. Piedra-Muñoz, L. Exploring synergies among agricultural sustainability dimensions: An empirical study on farming system in Almería (southeast Spain). Ecol. Econ. 2017, 140, 99-109. [CrossRef]

128. Sönmez, C.; Mamay, M. Biological control in sustainable agriculture. In Proceedings of the International GAP Agriculture \& Livestock Congress, Sanliurfa, Turkey, 25-27 April 2018.

129. Rodriguez-Rodriguez, M.; Galdeano-Gómez, E. Carmona-Moreno, E.; Godoy-Durán, A. Environmental impact, export inten-sity, and productivity interactions: An empirical index analysis of the agri-Food industry in Spain. Can. J. Agric. Econ. 2012, 60, 33-52. [CrossRef]

130. World Trade Statistical Review; World Trade Organization: Geneva, Switzerland, 2019; Available online: https://www.wto.org/ english/res_e/statis_e/wts2019_e/wts2019_e.pdf (accessed on 6 January 2020).

131. Pérez-Mesa, J.C.; Piedra-Muñoz, L.; Galdeano-Gómez, E.; Giagnocavo, C. Management Strategies and Collaborative Relationships for Sustainability in the Agrifood Supply Chain. Sustainability 2021, 13, 749. [CrossRef]

132. Sini, P. Long and short supply chain coexistence in the agricultural food market on different scales: Oligopolies, local economies and the degree of liberalisation of the global market. Eur. Sci. J. 2014, 10, 1857-7881.

133. Cagliano, R.; Worley, C.G.; Caniato, F.F.A. The Challenge of Sustainable Innovation in Agri-Food Supply Chains. In Organizing Supply Chain Processes for Sustainable Innovation in the Agri-Food Industry; Emerald: West Yorkshire, UK, 2016; pp. 1-30.

134. Tregear, A. Progressing knowledge in alternative and local food networks: Critical reflections and a research agenda. J. Rural Stud. 2011, 27, 419-430. [CrossRef]

135. Marsden, T.; Banks, J.; Bristow, G. Food Supply Chain Approaches: Exploring their Role in Rural Development. Sociol. Rural 2000, 40, 424-438. [CrossRef]

136. Kneafsey, M.; Venn, L.; Schmutz, U.; Balázs, B.; Trenchard, L.; Wood, T.E.; Bos, E.; Sutton, G.; Blackett, M. Short Food Supply Chains and Local Food Systems in the EU. A State of Play of Their Socio-Economic Characteristics; Joint Research Centre Institute for Prospective Technological Studies; European Commission: Brussels, Belgium, 2013.

137. Chen, H.; Jiang, W.; Yang, Y.; Yang, Y.; Man, X. State of the art on food waste research: A bibliometrics study from 1997 to 2014. J. Clean. Prod. 2017, 140, 840-846. [CrossRef]

138. Sala, S.; Anton, A.; McLaren, S.J.; Notarnicola, B.; Saouter, E.; Sonesson, U. In quest of reducing the environmental impacts of food production and consumption. J. Clean. Prod. 2017, 140, 387-398. [CrossRef]

139. van Bommel, H.W. A conceptual framework for analysing sustainability strategies in industrial supply networks from an innovation perspective. J. Clean. Prod. 2011, 19, 895-904. [CrossRef]

140. Salomone, R.; Saija, G.; Mondello, G.; Giannetto, A.; Fasulo, S.; Savastano, D. Environmental impact of food waste bioconversion by insects: Application of Life Cycle Assessment to process using Hermetia illucens. J. Clean. Prod. 2016, 140, 890-905. [CrossRef]

141. Silalertruksa, T.; Pongpat, P.; Gheewala, S.H. Life cycle assessment for enhancing environmental sustainability of sugarcane biorefinery in Thailand. J. Clean. Prod. 2017, 140, 906-913. [CrossRef]

142. Corrado, S.; Ardente, F.; Sala, S.; Saouter, E. Modelling of food loss within life cycle assessment: From current practice towards a systematization. J. Clean. Prod. 2016, 140, 847-859. [CrossRef]

143. Salemdeeb, R.; Zu Ermgassen, E.K.H.J.; Kim, M.H.; Balmford, A.P.; Al-Tabbaa, A. Environmental and health impacts of using food waste as animal feed: A comparative analysis of food waste management options. J. Clean. Prod. 2017, 140, 871-880. [CrossRef]

144. Lovins, A. Integrative Design: A Disruptive Source of Expanding Returns to Investments in Energy Efficiency; Rocky Mountain Institute: Basalt, CO, USA, 2010.

145. Kulak, M.; Nemecek, T.; Frossard, E.; Gaillard, G. Eco-efficiency improvement by using integrative design and life cycle as-sessment. The case study of alternative bread supply chains in France. J. Clean. Prod. 2016, 112, 2452-2461. [CrossRef]

146. Canto, N.R.D.; Bossle, M.B.; Vieira, L.M.; de Barcellos, M.D. Supply chain collaboration for sustainability: A qualitative investigation of food supply chains in Brazil. Manag. Environ. Qual. Int. J. 2020. [CrossRef]

147. Goossens, Y.; Berrens, P.; Charleer, L.; Coremans, P.; Houbrechts, M.; Vervaet, C.; de Tavernier, J.; Geeraerd, A. Qualitative assessment of eco-labels on fresh produce in Flanders (Belgium) highlights a potential intention-performance gap for the supply chain. J. Clean. Prod. 2017, 140, 986-995. [CrossRef]

148. Hall, J. Environmental supply chain dynamics. J. Clean. Prod. 2000, 8, 455-471. [CrossRef]

149. WFA. Trends in Environmental Assurance in Key Australian Wine Export Markets; Winemakers' Federation of Australia: Adelaide, Australia, 2007.

150. Strachan, S. A Statement of Policy and Programs to Deliver Greater Sustainability for the Australian Wine Sector; Winemakers' Feder-ation of Australia: Adelaida, Australia, 2007.

151. Atkin, S.; Launiala, A.; Kagaha, A.; Smith, H. Including mixed methods research in systematic reviews: Examples from qual-itative syntheses in TB and malaria control. BMC Med. Res. Methodol. 2012, 12, 62. [CrossRef] 